\title{
Reconstruction of Low and Middle Latitude Export Productivity, 30,000 Years BP to Present: Implications for Global Carbon Reservoirs
}

\author{
MICHAEL SARNTHEIN and KYAW WINN \\ Geologisch-Paläontologisches Institut \\ Christian-Albrechts-Universität \\ D-2300 Kiel \\ Federal Republic of Germany
}

\begin{abstract}
Based on organic carbon accumulation rates, nine time slices of oceanic export paleoproductivity $\left(P_{\text {new }}\right)$ are presented which depict the variability of $\mathbf{P}_{\text {new }}$ on a global scale through the last 30,000 years and document that the basic distribution patterns did not change through glacial and interglacial times. However, the glacial ocean shows an increased contrast of high- versus low-productivity zones. $\delta^{13} \mathrm{C}$ values of near-surface-dwelling planktonic foraminifera Globigerinoides ruber suggest that the same contrast applies to the glacial nutrient inventories of the ambient surface waters, with a significant glacial transfer of $\mathrm{PO}_{4}$ from low- to high-productivity zones. In this way, glacial $\mathrm{P}_{\text {new }}$ increased by a global average of about 2-4 Gt $\mathrm{Cyr}^{-1}$ and led, via an enhanced $\mathrm{CaCO}_{3}$ dissolution and alkalinity in the deep ocean, to a significant extraction of $\mathrm{CO}_{2}$ from the surface water and the atmosphere.
\end{abstract}

\section{INTRODUCTION}

Based on polar ice core studies, atmospheric carbon dioxide decreased by about $100 \mathrm{ppmv}$ during glacial stages 6 and 2, that is, by one-third of the atmospheric $\mathrm{CO}_{2}$ pressure found during interglacial stages 1 and 5.5 (Barnola et al., 1987). This glacial-to-interglacial difference had a considerable feedback on global climatic cooling and warming (Hansen et al., 1984) and on the climatic link between the Northern and Southern Hemispheres (Mitchell, 1988). The scientific community has largely agreed that combined variations in the "biological pump" (Berger and Keir, 1984) driving carbon dioxide into the deep ocean, and in the chemical and physical circulations of the ocean, must provide the dominant forcings for the observed changes in atmospheric $\mathrm{CO}_{2}$. In this context numerous models were proposed and examined in the literature (Sundquist and Broecker, 1985) 
Most recently, Boyle (1988) calculated and tested a model that recognizes the primary driving factor for atmospheric $\mathrm{pCO}_{2}$ change to be a glacial rearrangement of the vertical ocean chemistry distributions, that is, a global shift of labile nutrients and (isotopically light) metabolic $\mathrm{CO}_{2}$ from the Intermediate Water to the deep ocean. Sarnthein et al. (1988) observed a clear increase in biological productivity of wind-driven low- and midlatitude upwelling zones during the last glacial maximum (LGM) which enhanced the

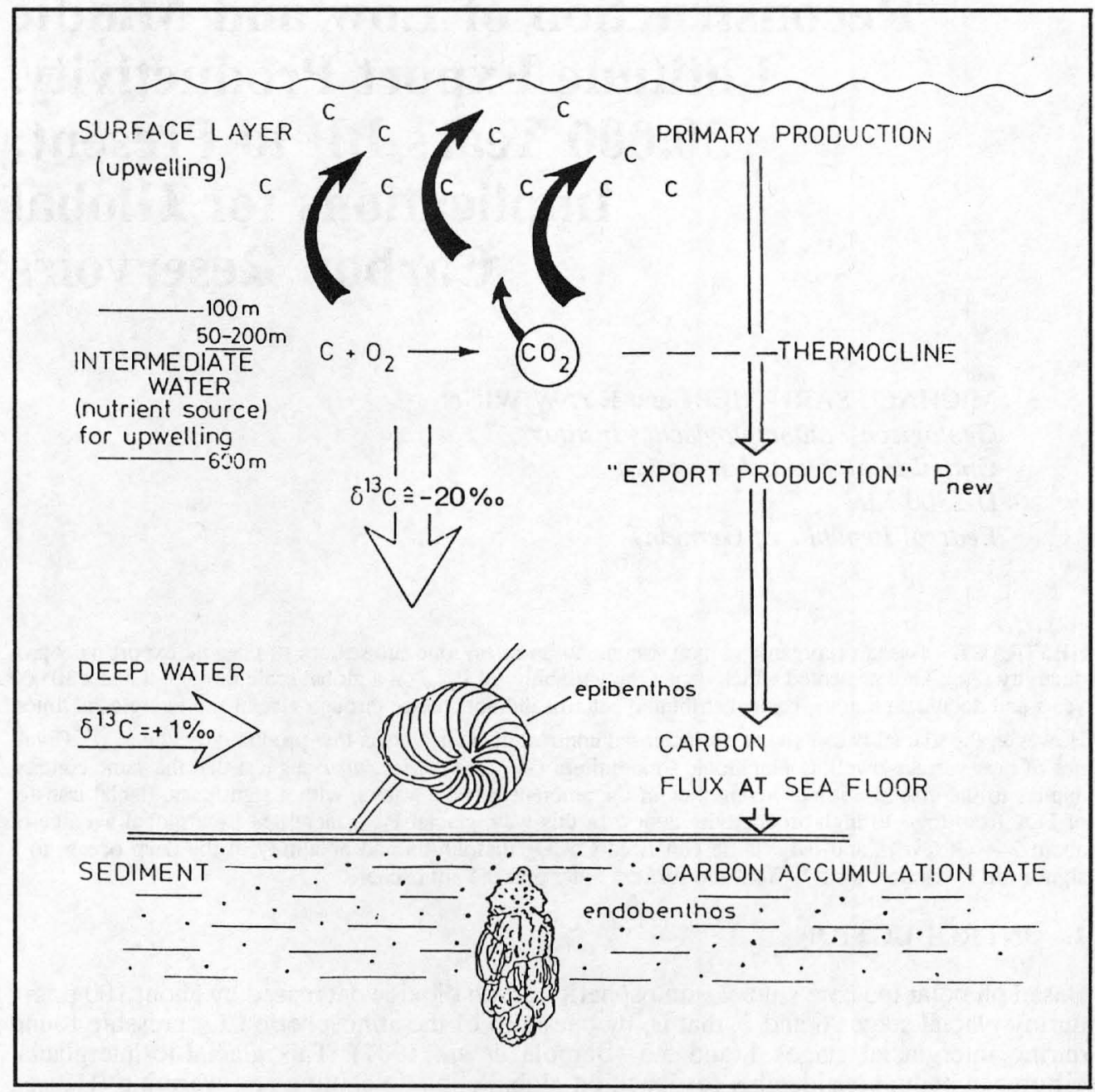

Figure 1. Basic pattern of organic carbon reservoirs in the ocean and their effect on the $\delta^{13} \mathrm{C}$ composition of benthic Foraminifera (from Altenbach and Sarnthein, 1989). G. ruber is considered to build its shells in the surface mixed layer of the ocean. C. wuellerstorfi represents an elevated epibenthic species such as indicated near the sea floor. 
annual global transfer of particulate organic matter (POC) by about 2-4 Gt C across the thermocline into the deep ocean. Strengthened currents in the level of the upper Intermediate Water $(<800 \mathrm{~m})$, such as the South Atlantic Central Water, were regarded as the main supply channels which probably fed additional nutrients from little-used highlatitude reservoirs to the glacial high-productivity zones in lower latitudes. Boyle (1988) suggested that the basin-wide vertical transfer of light carbon is integrated and reflected by the (reinterpreted) increased glacial carbon isotopic contrast between intermediate and surface water, and the bottom water $\left(\Delta \delta^{13} C_{\text {Plankton-Benthos }}\right)$. In harmony with Berger and Vincent (1986), Boyle (1988) inferred that the $\mathrm{CO}_{2}$-induced higher acidity of the bottom water temporarily increased the carbonate dissolution and, hence, the oceanic alkalinity. With a delay of about 3000 years, this higher alkalinity resulted in an extraction of $\mathrm{CO}_{2}$ from the atmosphere to the ocean, a mechanism that is related to, and enhances, the general effect of the organic carbon/carbonate carbon rain ratio proposed by Berger and Keir (1984).

In this chapter we trace back the spatial and temporal variability of oceanic export productivity in nine time slices through the last 30,000 years. Special attention is given to the narrow high-productivity belts in low latitudes. Based on the distribution patterns (Koblentz-Mishke et al., 1970) and empirical relationships found by Eppley and Peterson (1979) and Berger and Keir (1984), these belts may be expected to dominate the budgets of vertical carbon transfer in the ocean. Moreover, we document the carbon isotopic response of the ocean to paleoproductivity changes, in particular, the phase relationships between the oceanic response, productivity variations and atmospheric $\mathrm{pCO}_{2}$ changes, to arrive at a better understanding of the possible forcing chains for climatic change.

\section{EXPORT PALEOPRODUCTIVITY: PRINCIPLES OF RECONSTRUCTION AND CARBON ISOTOPIC RESPONSE}

Export productivity, $\mathbf{P}_{\text {new }}$, is the flux of sinking particulate organic matter that escapes recycling in the surface layer of the ocean by crossing the thermocline (Eppley and Peterson, 1979, Fig. 1). It amounts to $7-10 \%$ of the bulk primary production in lowproductivity zones and reaches more than $50 \%$ both in high-productivity belts and during short-term high-productivity events (Lochte and Turley, 1988). Only minor parts of $\mathrm{P}_{\text {new }}$ reach the deep ocean and the deep sea floor. Based on a combination of the partly modified concepts of Müller and Suess (1979), Suess (1980), and Eppley and Peterson (1979), we deduced values of export paleoproductivity from carbon accumulation rates in deep-sea sediments via the following empirical equation:

$$
\mathrm{P}_{\text {new }}=0.0238 \mathrm{C}^{0.6429} \mathrm{~S}_{\mathrm{B}}^{0.8575} \mathrm{DBD}^{0.5364} \mathrm{z}^{0.8292} \mathrm{~S}_{\mathrm{B}-\mathrm{C}}^{-0.2392}, \mathrm{gm}^{-2} \mathrm{yr}^{-1},
$$

where $\mathrm{C}$ is the concentration of organic carbon, $\mathrm{DBD}$ the dry bulk density, $\mathrm{S}_{\mathrm{B}}$ the bulk sedimentation rate, $\mathrm{S}_{\mathrm{B}-\mathrm{C}}$ the (organic) carbon-free sedimentation rate, and $\mathrm{z}$ the water depth. The correlation coefficient for measured versus calculated $P_{\text {new }}$ is $r=0.84$, suggesting that the presentation of the productivity signal is trustworthy.

A detailed discussion of Eq. (1) and its caveats is given in Sarnthein et al. (1987, 1988). These estimates of paleoproductivity reflect the ephemeral carbon output from pulsating bloom populations rather than the continuous "drizzle" from the day-to-day phytoplankton activity which is largely recycled in the surface layer of the ocean (Bruland et al., 1989).

The production of organic carbon is coupled with a strong fractionation of the isotopes. This leads to a $\delta^{13} \mathrm{C}$ depletion in planktonic organic matter and remineralized 
$\mathrm{CO}_{2}$ resulting in values of about $-20 \%$ as compared with more than $+1-2 \%$ (Broecker, 1982 ) in the $\Sigma \mathrm{CO}_{2}$ of the surface water, the latter of which is dominated by the exchange with the atmosphere (Fig. 1). As a result, the stable isotope composition of oceanic deep water reflects the contents of dissolved $\mathrm{CO}_{2}$ and nutrients, and thus forms a response to the intensity of both deep ocean physical and chemical circulations, and the vertical $\mathrm{C}_{\text {org }}$ fluxes from the sea surface productivity (e.g., Shackleton, 1977; Duplessy et al., 1980, 1984). Therefore, the $\delta^{13} \mathrm{C}$ signal of a foraminiferal species with elevated epibenthic microhabitats such as Cibicidoides wuellerstorfi (Lutze and Thiel, 1987, 1989) can serve as an ancient sensor of the basin-wide state of the geochemical organic carbon cycling in the deep sea (Zahn et al., 1986; Altenbach and Sarnthein, 1989). However, an enhanced local supply of organic fluff from high-productivity belts may bias this record by inducing an additional local depletion of the epibenthic $\delta^{13} \mathrm{C}$ signal by up to $0.45 \%$ (Kroopnick, 1971; Sarnthein et al., 1988), a feature that affects much more strongly the $\delta^{13} \mathrm{C}$ records of infaunal species such as Uvigerina sp. dwelling 1-6 mm below the sediment surface (Woodruff and Savin, 1985; Berger and Vincent, 1986; Zahn et al., 1986; recent direct observations by Altenbach and Sarnthein, 1989).

Berger and Vincent (1986) and Curry and Crowley (1987) gave recent summaries on the carbon isotopic record of planktonic foraminifers which is far more difficult to interpret than the benthic signal because: (i) the regional and seasonal patterns of nutrients and carbon isotopes near the ocean surface vary substantially both vertically and between seasons, and (ii) the life habitats, vital and symbiotic effects of different planktonic foraminiferal species and foraminiferal life stages vary greatly (Fairbanks et al., 1982; Ganssen, 1983; Curry et al., 1983). A few species produce their tests dominantly in the subsurface layer, for example, Neogloboquadrina dutertrei, N. pachyderma and Globorotalia inflata. Other species such as Globigerinoides ruber and G. sacculifer dwell in the surface mixed layer (Deuser et al., 1981) and may provide a $\delta^{13} \mathrm{C}$ record of the seasonal nutrient depletion or enrichment in the surface ocean (Deuser and Ross, 1980), a record which markedly differs from that of the thermocline and further below (Deuser et al., 1981). In addition, the carbon isotopic record of $G$. ruber, such as that of other species, may be subject to some error due to vital effects. The depth habitat of the formation of Globigerina bulloides tests still appears controversial, but its light carbon isotopes probably reflect the composition of the subsurface layer (Ganssen, 1983).

Shackleton et al. (1983) first documented an increased glacial carbon isotopic contrast between the surface and deep ocean. Based on the principles outlined above, the stronger contrast can be derived, in theory, from three possible rearrangements of the nutrient distribution in the ocean, each time at the expense of the Intermediate Water, this as demonstrated by Zahn et al. (1987), Duplessy et al. (1988), Kallel et al. (1988) and Boyle (1988). These three possible rearrangements are: (i) both the deep ocean and the surface ocean may have been $\mathrm{CO}_{2}$ and nutrient enriched, but the deep ocean somewhat more strongly (Broecker, 1982); (ii) the nutrient and $\mathrm{CO}_{2}$ budgets of the surface layer remained as today, only the deep water was enriched; and (iii) the deep ocean was $\mathrm{CO}_{2}$ and nutrient enriched at the expense of both the Intermediate and surface waters.

In their critical review of six glacial-to-interglacial $\delta^{13} \mathrm{C}$ records obtained from the surface dwelling species G. sacculifer in the Atlantic, Curry and Crowley (1987) clearly demonstrated that the glacial ambient surface water near the equator was generally ${ }^{13} \mathrm{C}$ depleted by about $0.2 \% 0030-16 \mathrm{ky}$ ago, and by up to $0.5 \%$ at $16-9 \mathrm{ky} \mathrm{BP}$, that is, it was nutrient enriched (Broecker, 1982). In contrast, a $\delta^{13} \mathrm{C}$ record of the surfacedwelling species $G$. ruber from the low-productivity Sargasso Sea shows a last glacial 
${ }^{13} \mathrm{C}$ increase by more than $0.3 \%$, indicating a regional nutrient depletion, at least seasonally. For example, Deuser and Ross (1980) reported a modern annual range of net primary productivity variations, hence nutrient variations, near Bermuda by a factor of 4 . This range probably was much reduced during glacial times, and the average values lower, as shown by the results of Curry and Crowley (1987). Based on G. ruber in a Caribbean core (Broecker, 1982), analysis reveals a $\delta^{13} \mathrm{C}$ increase of more than $0.5 \%$, that is, possibly an even stronger nutrient exhaustion. In contrast, a subsurface $\delta^{13} \mathrm{C}$ record of $N$. dutertrei from the east Pacific core V19-30 (Shackleton et al., 1983) remains difficult to interpret because this species calcifies within the nutrient-enriched thermocline and strongly feeds on symbiotic algae (Hemleben et al., 1989). Similarly, the respective $\Delta \delta^{13} C_{\text {Plankton-Benthos }}$ record, where $\Delta$ indicates the glacial-interglacial difference, is difficult to interpret. Accordingly, we may expect a more polarized distribution of the nutrient inventory in the glacial surface ocean than for the distribution today, with a shift from the widespread low-productivity zones to the narrow high-productivity zones. Furthermore, this shift will induce a general increase in the 'rain ratio,' which varies nonlinearly with the strength of the productivity (Berger and Keir, 1984) and produces, in turn, an increase in (deep) ocean alkalinity (Boyle, 1988). This mechanism possibly has the potential to explain the carbonate dissolution spikes that are characteristic of the abrupt climatic change linked to the onset of glaciations.

In this study we supplement the data on paleoproductivity by a set of related planktonic $\delta^{13} \mathrm{C}$ data which record glacial-to-interglacial regional changes of nutrient concentrations in the surface mixed water. Moreover, we try to add to the understanding of the $\Delta \delta^{13} \mathrm{C}_{\text {(Plankton-Benthos) }}$ values which may record a wide variety of different rearrangements of the ocean chemistry distribution.

Stable isotopic records and chronostratigraphy of most cores were obtained from Zahn-Knoll (1986) and Sarnthein et al. (1988). The stratigraphy of further cores and additional $\delta^{13} \mathrm{C}$ values for $G$. ruber $(315-400 \mathrm{~mm})$ were derived from Sarnthein et al. (1984), Pflaumann (1989), Kassens and Sarnthein (1989), Sirocko (1989), and from Duplessy (1981), Fontugne and Duplessy (1981, 1986), Curry and Crowley (1987) and Broecker (1982).

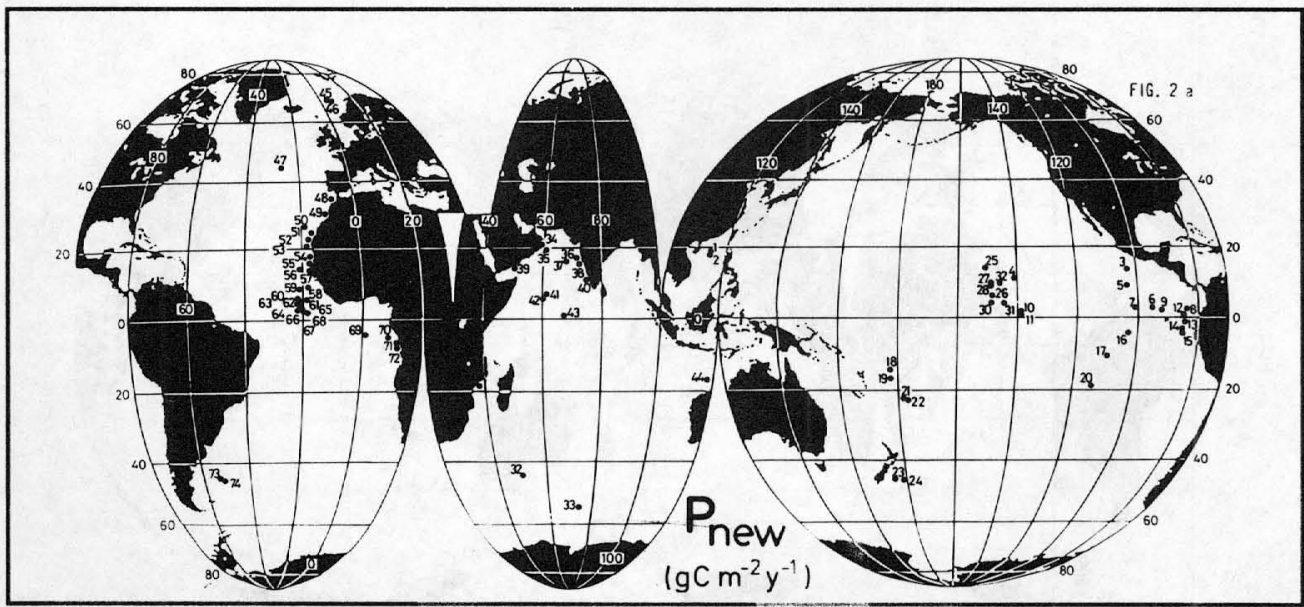

Figure 2. Maps of the global distribution patterns of export productivity $\mathrm{P}_{\text {new }}$ during the past 30,000 years in nine time slices as indicated $(a-j) . P_{\text {new }}$ estimates are obtained from Eq. 1. Dotted lines demarcate areas of data extrapolation. The numbers in Figure 2a refer to the cores listed in Table 1. 


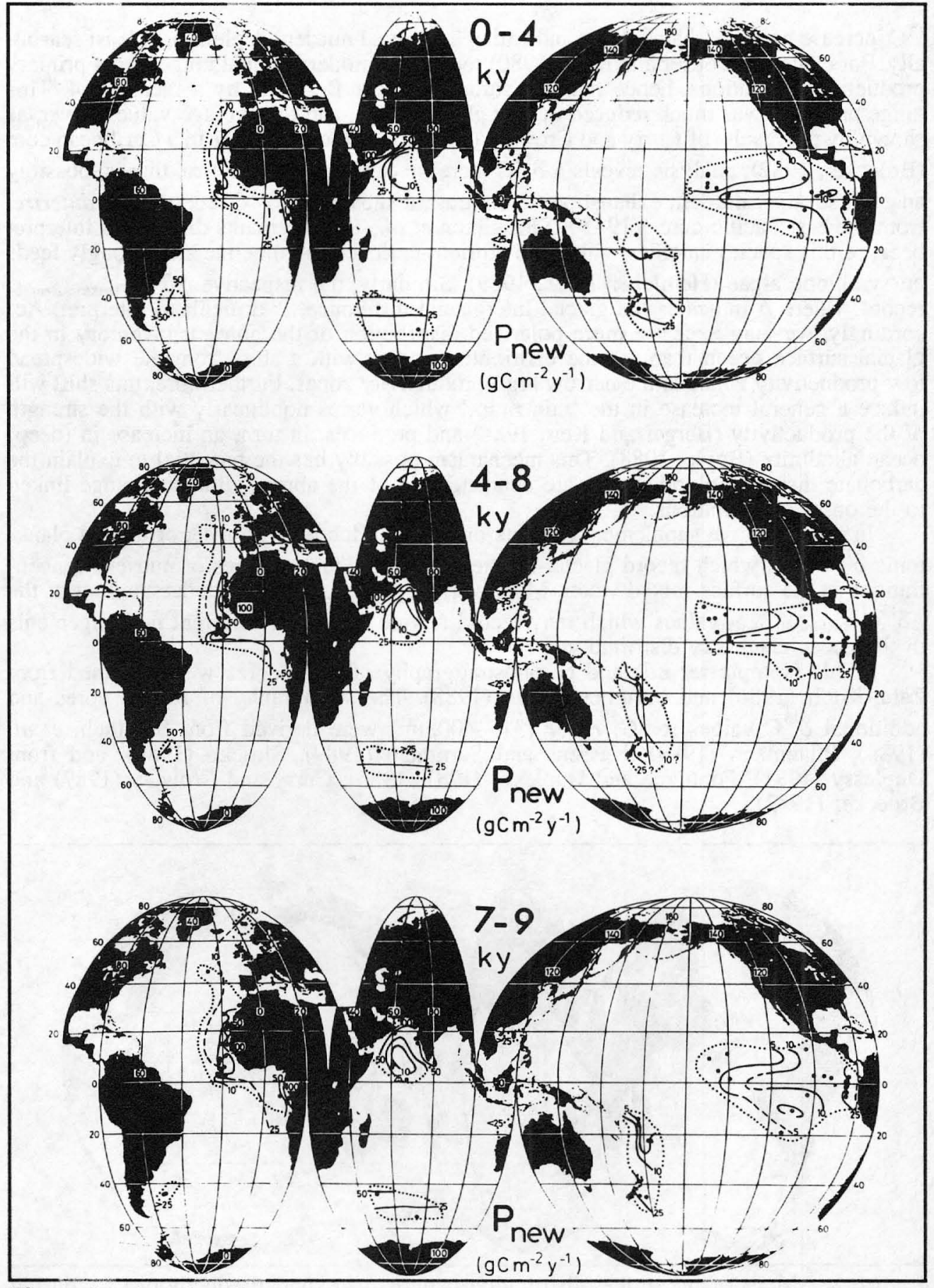

Figure 2. (continued) 


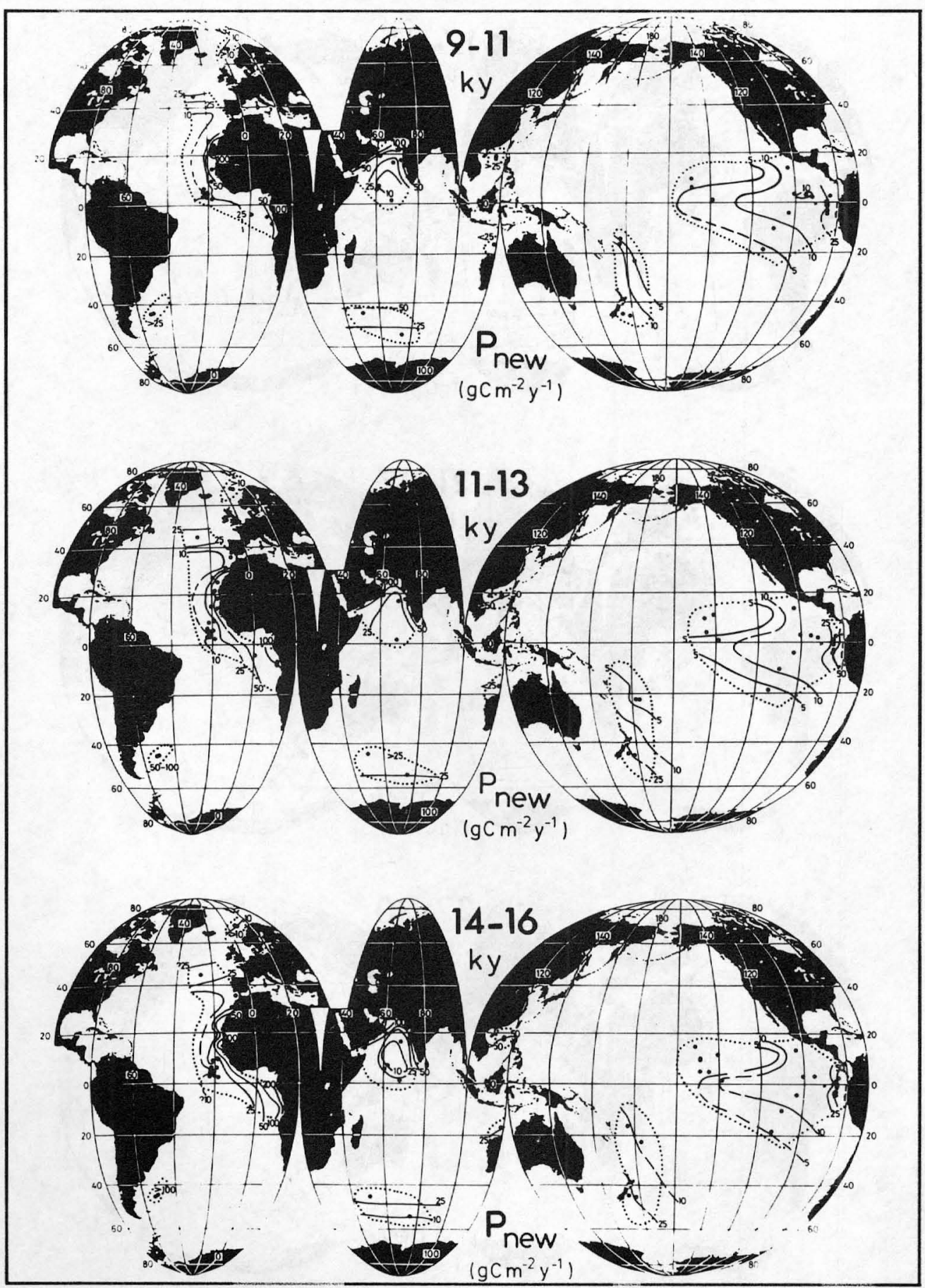

Figure 2. (continued) 


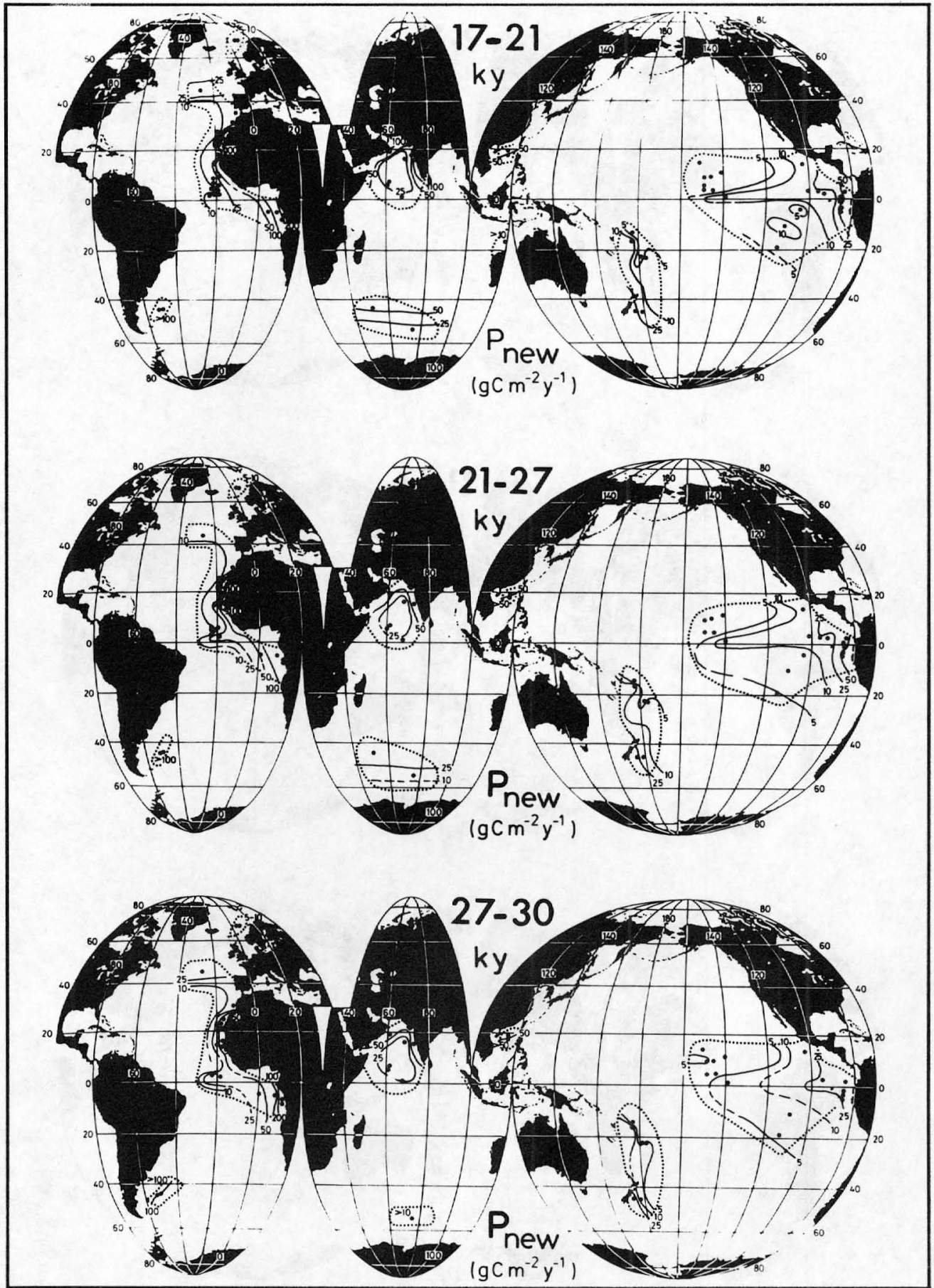

Figure 2. (concluded) 
Table 1. $\delta^{13} \mathrm{C}$ values of Globigerinoides ruber for 0-8ky and 17-21ky, together with the global Export Production values for the past 30,000 years in 9 time slices. For core locations see Fig. 2a.

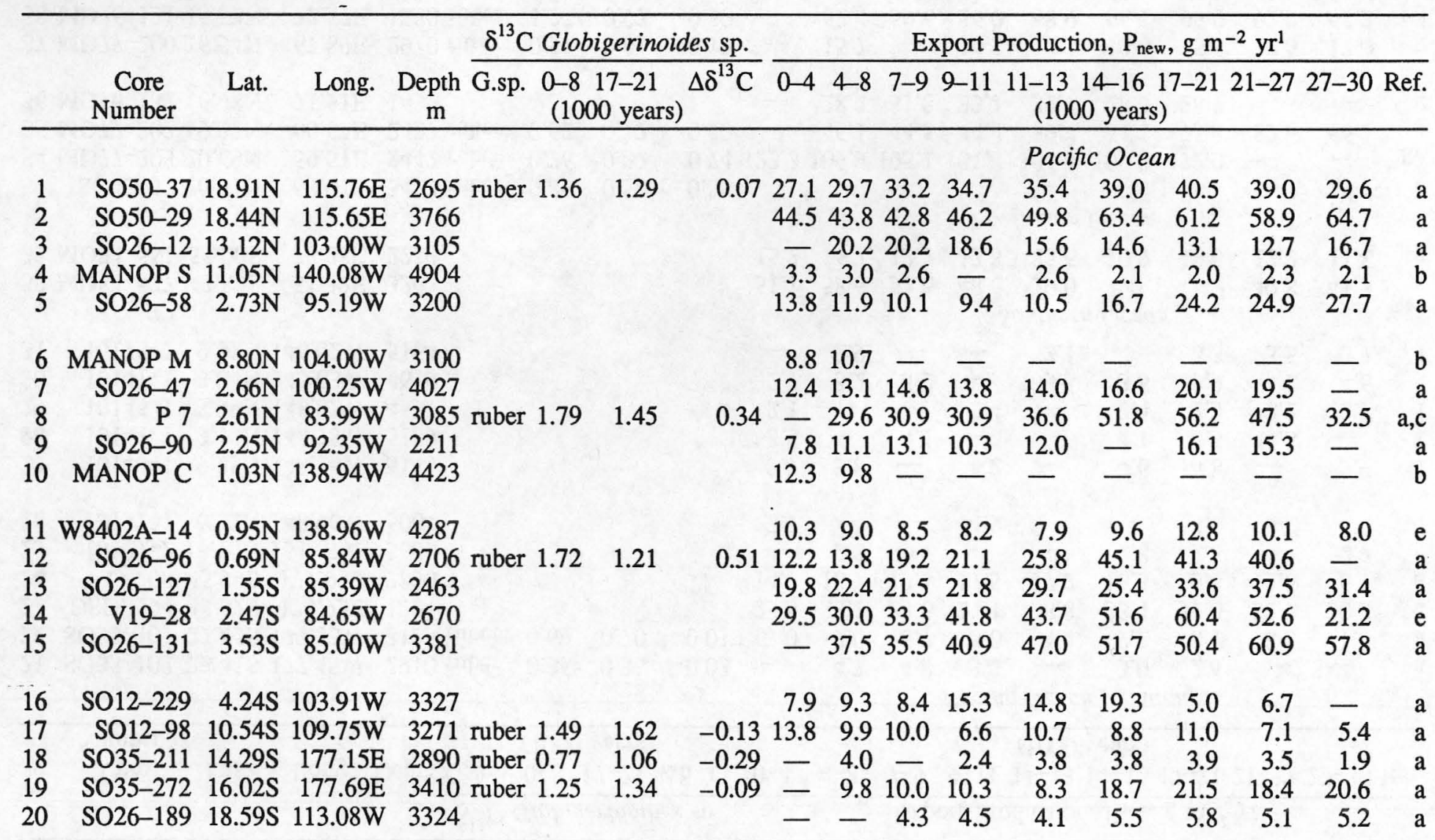


Table 1. (continued)

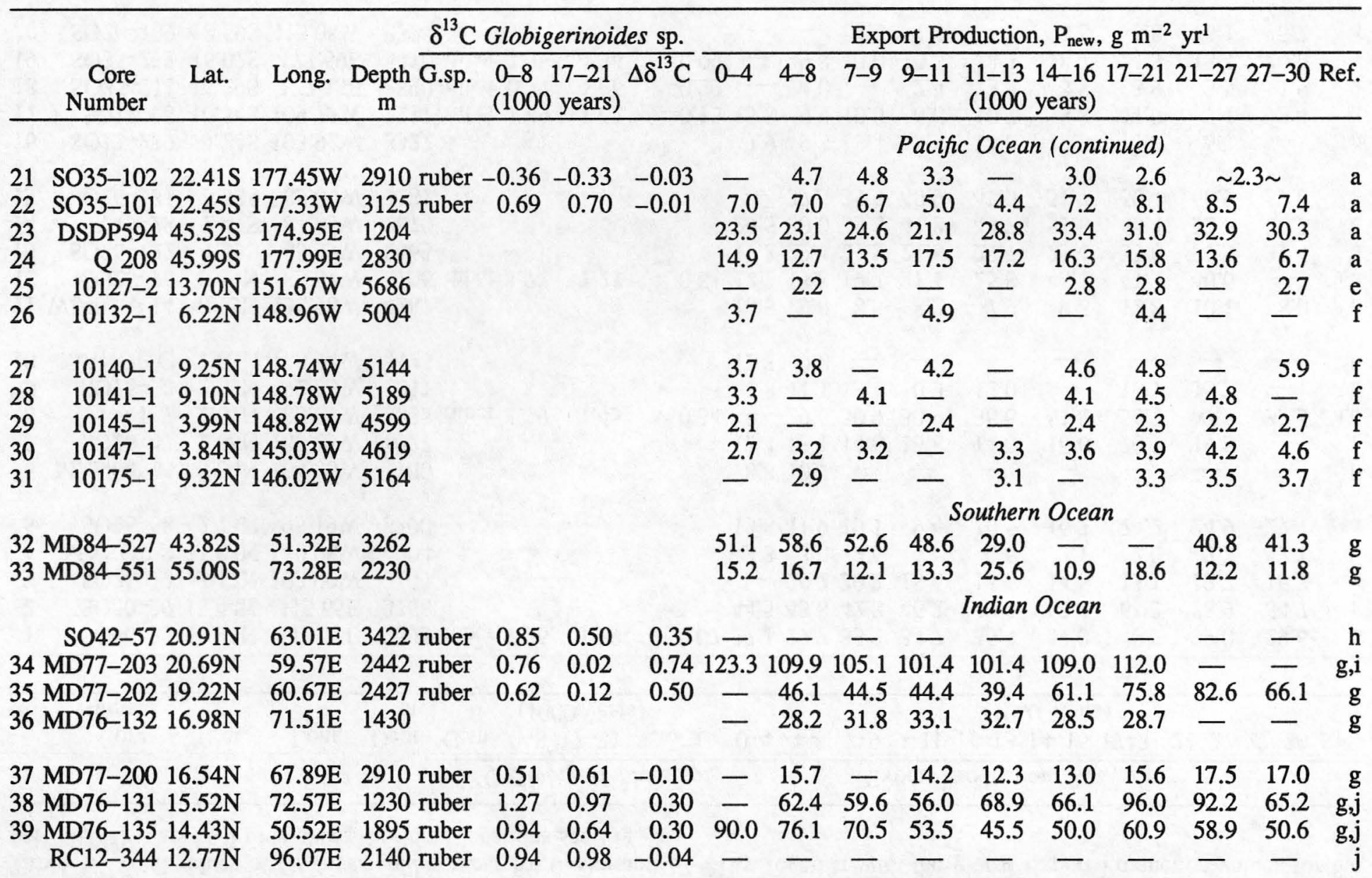


Table 1. (continued)

\begin{tabular}{|c|c|c|c|c|c|c|c|c|c|c|c|c|c|c|c|c|}
\hline & & & & $\delta^{13} \mathrm{C} \mathrm{Glob}$ & igerinc & des sp. & & & & port $\operatorname{Pr}$ & roduc & n, $P_{\text {new }}$ & $g$ & $2 \mathrm{yr}^{1}$ & & \\
\hline & $\begin{array}{c}\text { Core } \\
\text { Number }\end{array}$ & Lat. & Long. & $\begin{array}{cc}\text { Depth G.sp. } & 0-8 \\
\mathrm{~m} & (100 \\
\end{array}$ & $\begin{array}{l}17-21 \\
0 \text { years) }\end{array}$ & $\Delta \delta^{13} \mathrm{C}$ & $0-4$ & $4-8$ & $7-9$ & $9-11$ & $\begin{array}{r}11-13 \\
(1000 \\
\end{array}$ & ea & & $1-$ & & Ref. \\
\hline & & & & & & & & & & & & & & & & \\
\hline & MD77-171 & $11.75 \mathrm{~N}$ & $94.15 \mathrm{E}$ & 1760 ruber 0.86 & 1.05 & -0.19 & - & 一 & 一 & 一 & - & - & 一 & - & - & J \\
\hline & 9 & & 95.1 & r 0.96 & & & & - & & - & - & & - & & & \\
\hline 0 & 94 & $10.47 \mathrm{~N}$ & 75.2 & 1222 & & & 104.3 & 78.3 & 69.0 & 88.1 & 96.1 & 100.4 & - & & - & 0 \\
\hline 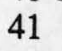 & -5 & $6.66 \mathrm{~N}$ & $61.13 \mathrm{E}$ & 3335 ruber 1.30 & 1.24 & 0.06 & 9.3 & 10.0 & 10.0 & - & 9.4 & .3 & 13.3 & 12.8 & 12.6 & $\mathrm{~g}, \mathrm{~h}$ \\
\hline & & & & 1.25 & & & - & & 22.3 & & & & & & 9 & ${ }_{g, 11}$ \\
\hline & 28 & $\mathrm{~N}$ & $E$ & 101 ruber 1.40 & & 0.06 & 17.9 & 13.7 & 16.9 & & 15 & & & & .8 & $\mathrm{~g}, \mathrm{~h}$ \\
\hline $3 a$ & $672-1$ & & & 390 ruber 1.06 & & 0.19 & 7.7 & 8.8 & 5.2 & & & & & 4.4 & 6.3 & a \\
\hline & $14807-1$ & & & 1186 ruber 1.24 & & & 20.5 & 23.5 & 23.4 & 23.3 & 22.8 & & 22.0 & & - & $\mathbf{k}$ \\
\hline & & & & & & & & & & & 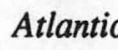 & & & & & \\
\hline 45 & & & $4.02 \mathrm{E}$ & 2308 & & & 12.2 & 12.0 & 10.6 & 10 & 11 & & & 9.8 & 9.8 & a \\
\hline 0 & & & $5.23 \mathrm{E}$ & 8 & & & 19.0 & 15.0 & 14.6 & 11 & & & & & 6.7 & a \\
\hline 7 & -2 & $9 \mathrm{~N}$ & $26.54 W$ & 3050 & & & - & 2.4 & 7.0 & 25.3 & 36 & & & 21.9 & 30.5 & a \\
\hline & & & & 2455 ru & & $\ldots$ & - & 24.5 & - & & & & & - & - & $\mathrm{a}, \mathrm{l}$ \\
\hline & & & & er 1.08 & & & 16.1 & & 20.4 & & & & & 14.7 & .5 & a,l \\
\hline 50 & & 2 & 18 & er - & 0 & - & - & 25.2 & 24.8 & 20.8 & 1 & & & 8.6 & .1 & $a, 1$ \\
\hline 51 & -1 & $7 \mathrm{~N}$ & $16.85 \mathrm{~W}$ & 2575 ruber 1.18 & 0.5 & 0.62 & 22.0 & 22.4 & 23.5 & 74.9 & 77.6 & 94.6 & 101.4 & 102.1 & 79.8 & g,j \\
\hline & & & & .28 & & & 48.8 & & $J$ & & & & & & & $\mathrm{a}, 1$ \\
\hline & 1 & & 18 & 1.32 & & 53 & 68.9 & 74.7 & 88.9 & 101.3 & & & & 2 & 84.4 & a,1 \\
\hline 54 & $13289-2$ & $18.07 \mathrm{~N}$ & $18.01 \mathrm{~W}$ & 2490 ruber 1.34 & 0.90 & 0.44 & - & 38.5 & 45.4 & 43.6 & & & & & - & $a, 1$ \\
\hline 55 & & $15.83 \mathrm{~N}$ & $17.86 \mathrm{~W}$ & 2576 & & & 166.7 & 105.6 & - & - & 107.4 & & & & 一 & a \\
\hline 56 & 164 & $14.46 \mathrm{~N}$ & $20.54 W$ & 4234 & & & 33.9 & 30.2 & 27.2 & 27.1 & 30.2 & & 8 & 32.5 & 27.9 & a \\
\hline 57 & 13239-1 & $13.88 \mathrm{~N}$ & $18.31 \mathrm{~W}$ & 3156 ruber & 1.05 & 0.6 & - & 55.9 & 60.5 & 80.0 & 56.8 & & 98.0 & 98.2 & 103.7 & $a, 1$ \\
\hline 58 & $16415-1 / 2$ & $9.57 \mathrm{~N}$ & $19.11 \mathrm{~W}$ & 3841 & & & 27.3 & 25.3 & 21.9 & 22.1 & 22.4 & 21.7 & 28.2 & - & - & $a, n$ \\
\hline
\end{tabular}


Table 1. (concluded)

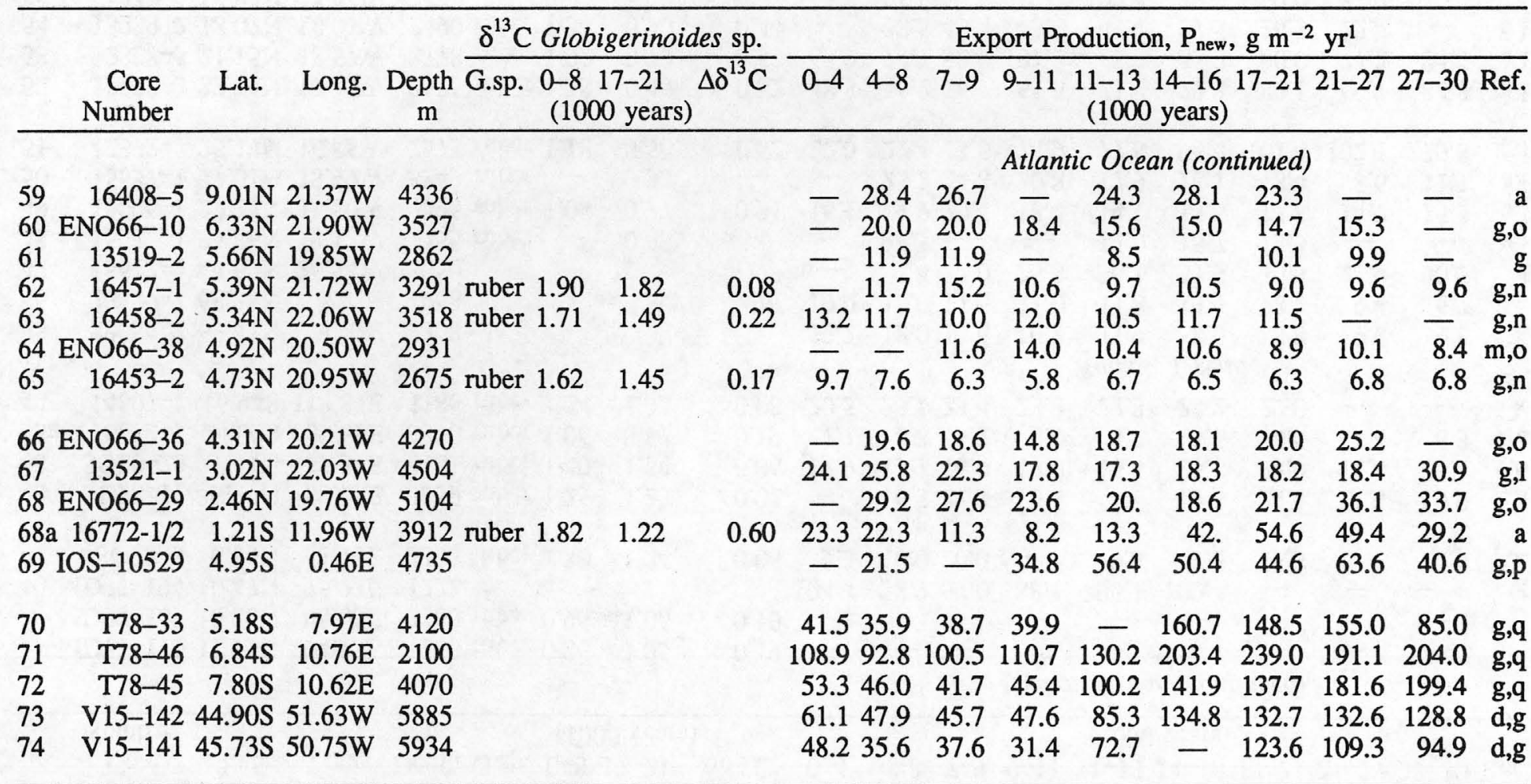

References: a, this work; b, Emerson et al. (1985); c, Pederson et al. (1988); d, Stevenson and Cheng (1972); e, Lyle et al. (1988); f, Müller and Mangini (1980); g, Sarnthein et al. (1988); h, F. Sirocko (1989); i, Fontugne and Duplessy (1986); j, Duplessy (1981); k, Zahn (1982); 1, Zahn-Knoll (1986); m, Curry \& Crowley (1987); n, H. Kassens (pers. comm.); o, Curry and Lohmann (1985); p, Morris et al. (1984); q, Jansen et al. (1984). 


\section{RESULTS AND DISCUSSION}

\subsection{Temporal and Spatial Variability of $\mathbf{P}_{\text {new }}$}

$\mathrm{P}_{\text {new }}$ records of 74 cores from the Pacific, Indian and Atlantic Oceans were averaged in nine time slices covering the last 30,000 years (Table 1 and Fig. 2). The time range of the slices varies, and they were selected with the intent of characterizing the distributional patterns of $\mathrm{P}_{\text {new }}$ during particular short-term phases and events of climate generally recognized on oxygen isotopic curves. These include, for example, a last pre-glacial phase 27-30 ky BP; the state of early, peak and latest glaciation (21-27, 17-21, and 14-16 ky BP); the Alleröd warm phase (11-13 ky BP); the Younger Dryas cooling (9-11 ky BP); and two versions of the early Holocene climatic optimum (7-9 and 4-8 ky BP). The range of the "Recent" time slice (0-4 ky BP) is broad because many core locations lack a reliable surface sediment record. However, the detailed match of the Recent $P_{\text {new }}$ data with those 4-8 ky ago may suggest that the Holocene patterns and intensities of $P_{\text {new }}$ remained fairly constant. Also, the time slice 7-9 ky BP hardly differed from that of 4-8 ky ago. The only exceptions occur in the upwelling zones off the Congo and off the south Arabian coast where $\mathrm{P}_{\text {new }}$ increased by 10-25\% during the late Holocene. In general, the spatial distribution pattern closely follows the well-known productivity patterns mapped by Koblentz-Mishke et al. (1970), that is, comparatively narrow high-productivity belts parallel to the equator, the eastern ocean margins in low latitudes, the margins of the Arabian Sea, and the higher middle latitudes of the circum-Antarctic ocean. These contrast with much wider extended areas where productivity is low.

In near-shore areas an important fraction of the organic carbon registered in our samples may originate from riverine supply of organic matter (Ittekkot, 1988) and thus bias our paleoproductivity data. However, both first isotopic data of the organic carbon fraction and C/N data (summarized in Sarnthein et al., 1988; L. Westerhausen, letter to M. Sarnthein, November, 1988) imply that the bulk of organic matter originates from the marine plankton production, except for a few of the shallower sites such as off the mouth of the Senegal river and in the northern Bay of Bengal (not included in the data set, Table1). It appears that most of the riverine organic matter is deposited in the estuaries and on the shelf and upper slope.

The basic patterns of the $\mathrm{P}_{\text {new }}$ distribution persisted in the time slices 9-27 ky BP and further back. However, the intensities changed in several key areas. Only in the Atlantic do we observe a new glacial high-productivity region (from $2.5^{-2}$ to $35 \mathrm{gC} \mathrm{m}^{-2}$ $\left.\mathrm{yr}^{-1} \mathrm{P}_{\text {new }}\right)$ emerging north of the Azores which lasted from 9-30 ky BP. We interpret this as the result of an ancient North Atlantic divergence zone similar to that in the present South Atlantic. This North Atlantic divergence zone probably ceased after the perennial current advection to the Norwegian Sea had been established at about 9 ky BP (Jansen and Erlenkeuser, 1984). The glacial high-productivity belts in the near-shore upwelling areas along the Atlantic eastern margin off Africa were much enhanced (by about $150 \%$ ), likewise off South Argentina (by $200 \%$ ). In contrast, various locations in the low-productivity subtropical Atlantic further offshore (e.g., on the western and southern Sierra Leone Rise) and in the Norwegian Sea show a slight decrease in productivity. Based on the distribution of planktonic foraminiferal species, Mix (1989) arrived at basically similar trends, a general increase in LGM paleo-(primary) productivity of the Atlantic, particularly beneath the equator. Some different patterns in middle latitudes have yet to be explained. In the Indo-Pacific region similar trends are observed. Glacial productivity was higher by up to $50-100 \%$ in the upwelling belts of the equatorial eastern Pacific; by up to $50 \%$ in the Fiji-Lau Basin, off east New Zealand, and in the South China Sea; by 

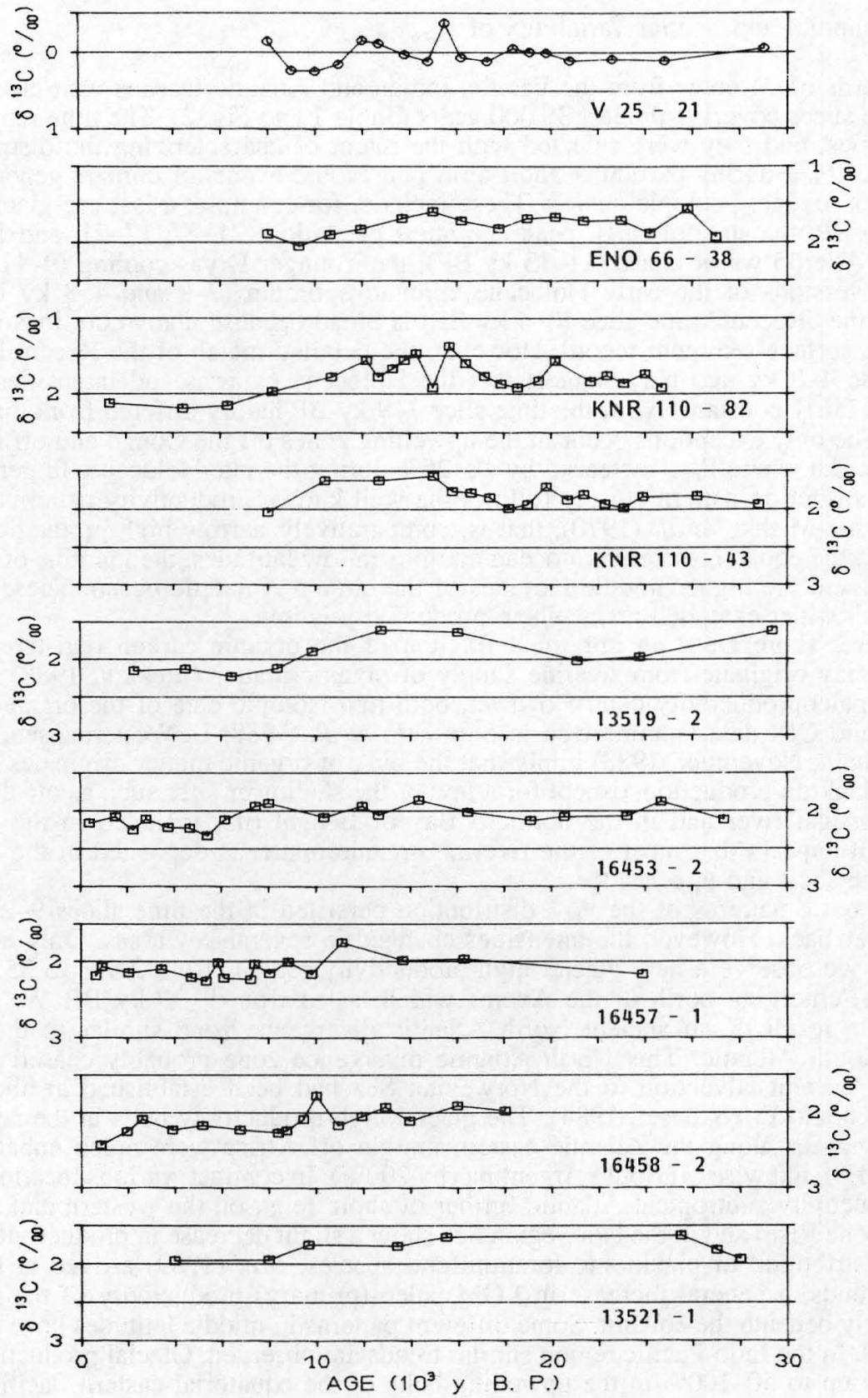

Figure 3a. Planktonic $\delta^{13} \mathrm{C}$ curves of G. ruber. For core locations and credits refer to Table 1 . 

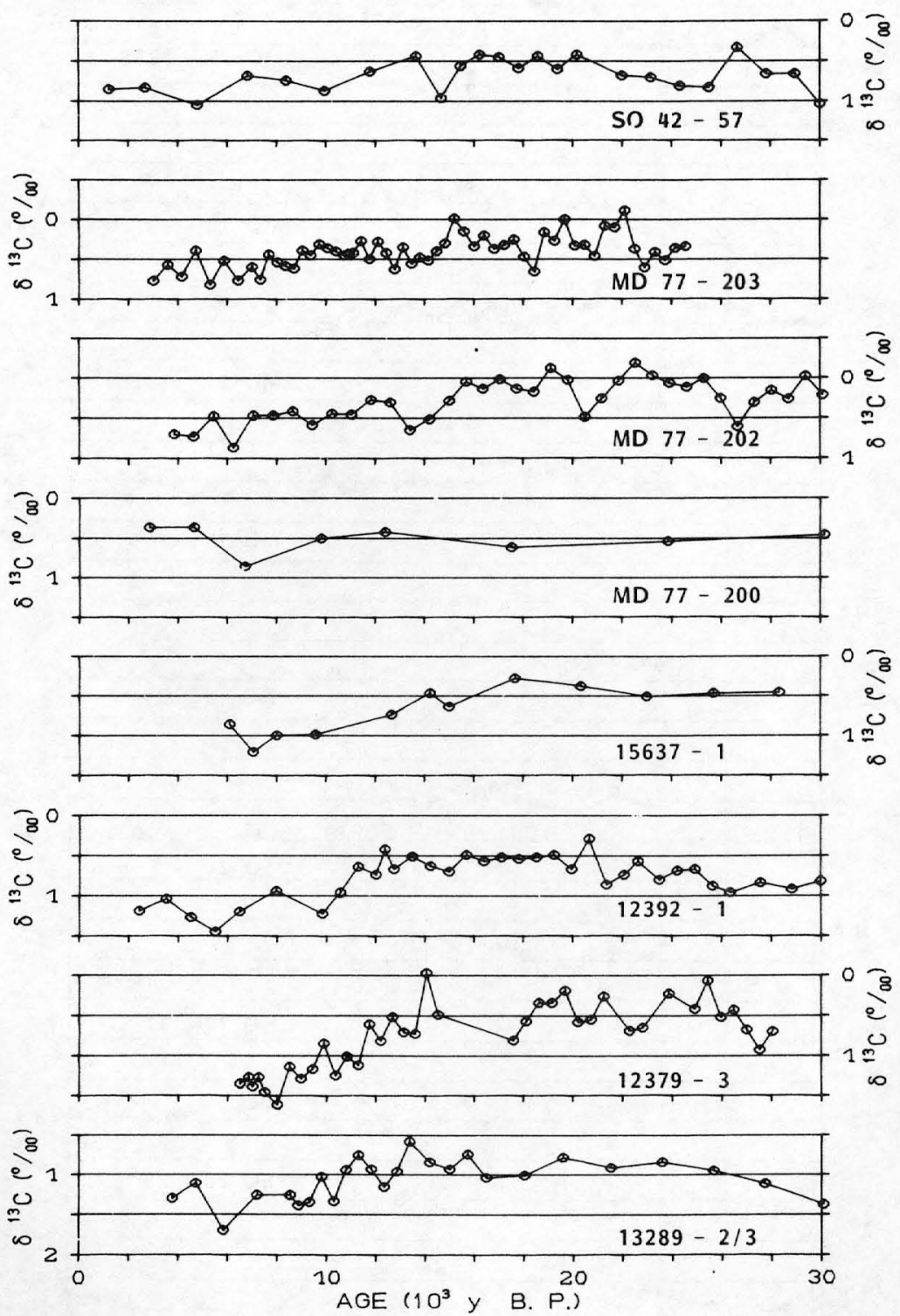

Figure 3b. (continued) 

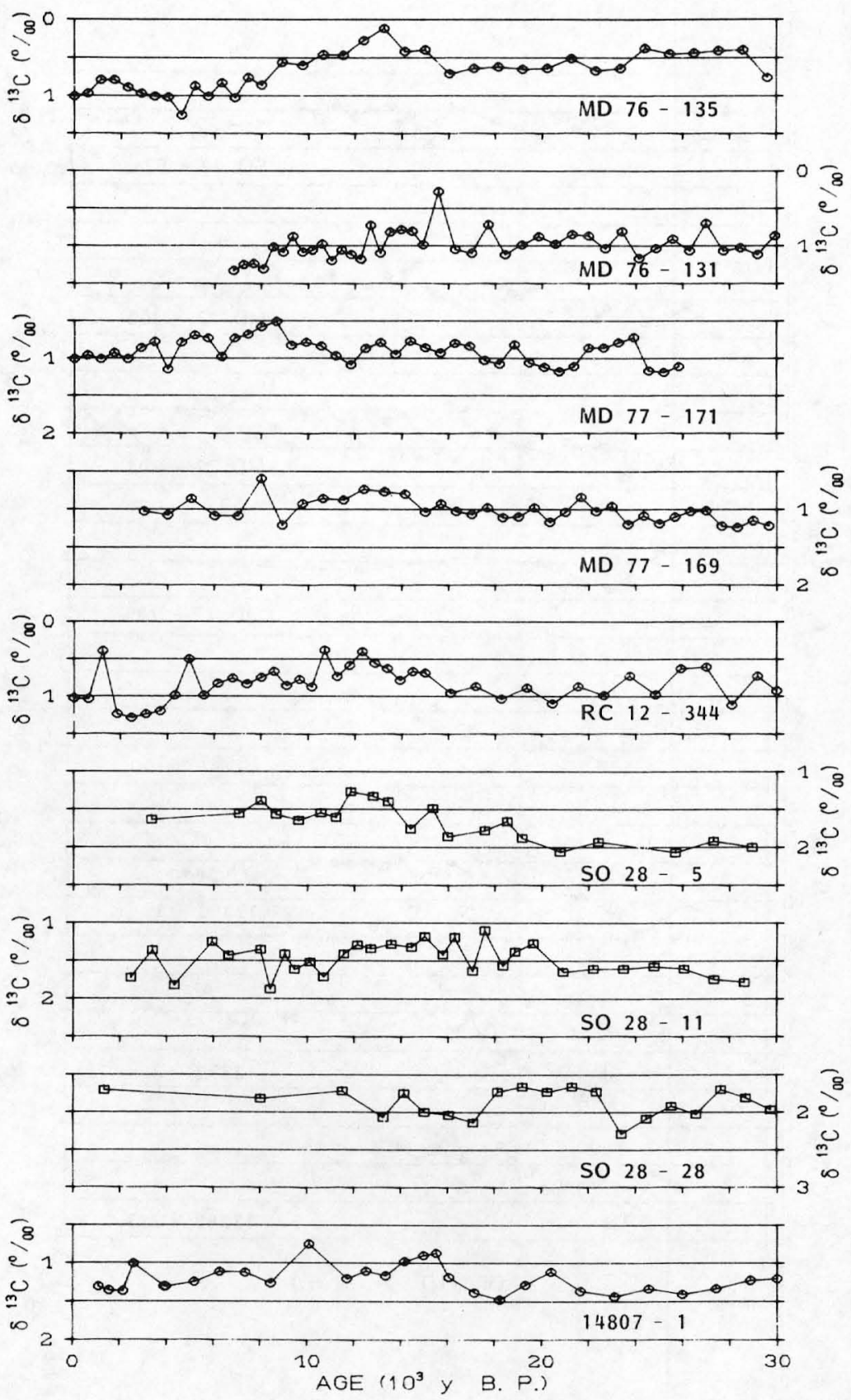

Figure 3c. (continued) 

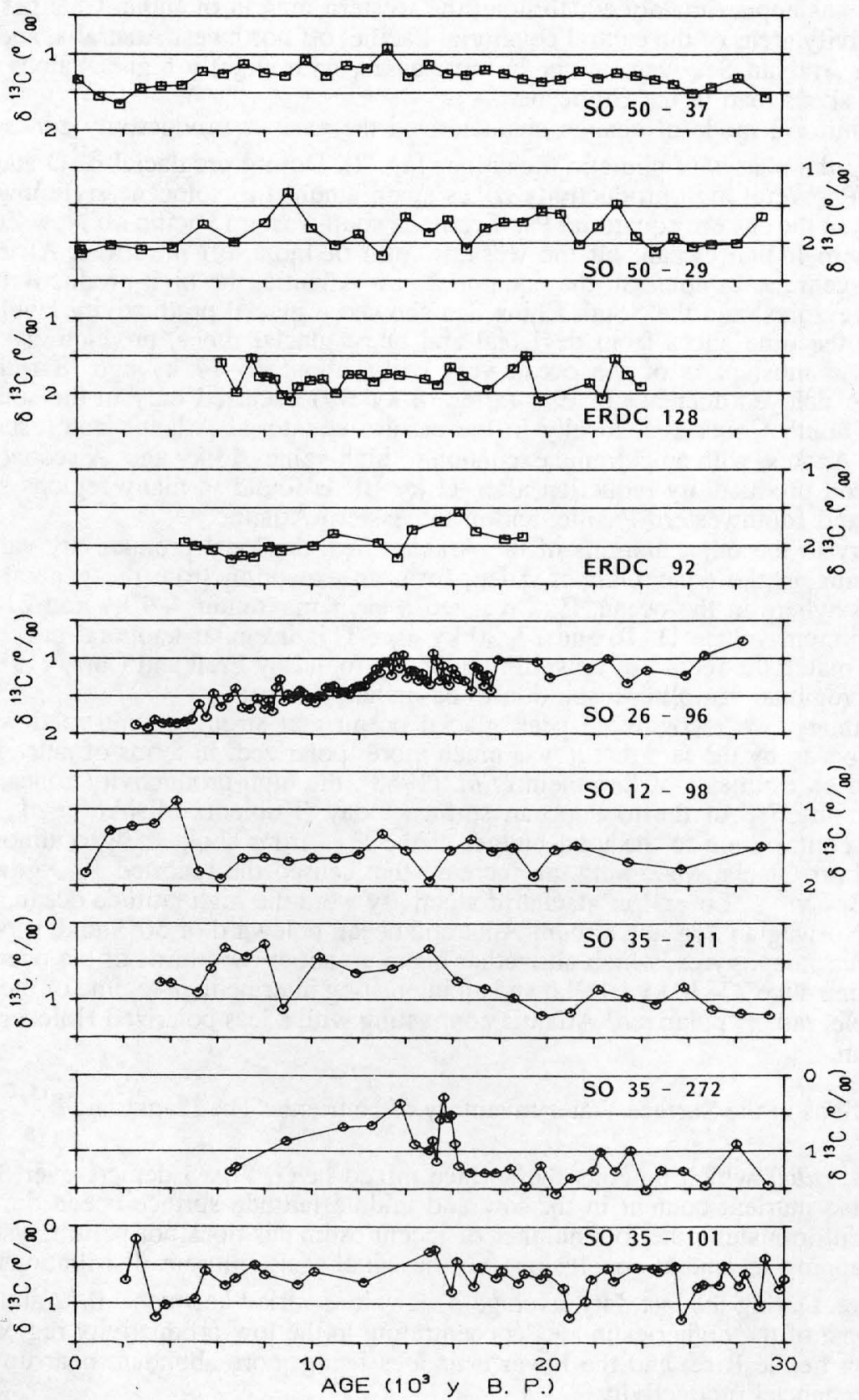

Figure 3d. (concluded) 
up to $70 \%$ in the western equatorial Indian Ocean; by only $10 \%$ in the southern Indian Ocean; and was approximately equal along the western margin of India. Changes in the low-productivity areas of the central equatorial Pacific, off northwest Australia, and in the southeastern Arabian Sea were minor in most cases, with slightly higher values during glacial time slices than in the Holocene.

A nonuniform mode of change characterized the various productivity zones of the ocean during the phases of climatic transition (Fig. 2). During preglacial $\delta^{18} \mathrm{O}$ stage 3.1, $27-30 \mathrm{ky} \mathrm{BP}$, several high-productivity zones again attained a Holocene-style low level, for example, in the eastern equatorial Pacific, in the southwestern Pacific off New Zealand, in the southern Indian Ocean, off the western coast of India, off northwest Africa, and off south Argentina. In contrast, the equatorial east Atlantic, the high-productivity zone north of the Azores, and the South China Sea showed a glacial productivity level.

During the time slices from deglacial and latest glacial times, productivity started to decrease in most parts of the ocean very early, about 16-17 ky ago (Sarnthein et al., 1988). A delayed decrease in $\mathrm{P}_{\text {new }}$ (after $14 \mathrm{ky}$ BP) occurred only in the southwest Pacific, the South China Sea, locally in the eastern equatorial Atlantic and, especially, north of the Azores, with an extreme excursion to high values $13 \mathrm{ky}$ ago. A second phase of pronounced productivity reduction after $11 \mathrm{ky} \mathrm{BP}$ is found in many regions such as the eastern and southwestern Pacific, and in the eastern Atlantic.

Contrary to the other margins of the Arabian Sea, the local productivity variations off Hadramaut, in the outer Gulf of Aden, form an exception from the general trends observed elsewhere in the ocean. $\mathrm{P}_{\text {new }}$ reached a clear maximum 4-9 ky and 21-27 ky $\mathrm{BP}$, and minimum values 11-16 and 27-30 ky ago. This irregular temporal pattern does not directly match the record of upwelling intensity found by Prell and Curry (1980) and needs more regional sampling resolution to be understood better.

In summary, we recognize a peak glacial ocean that strongly contrasted with the interglacial ocean by the fact that it was much more 'polarized' in terms of paleoproductivity. Based on estimates of Sarnthein et al. (1988), the high-productivity zones, which comprise about $37 \%$ of the total ocean surface today (Koblentz-Mishke et al., 1970), raised their contribution to the total budget of the $\mathrm{P}_{\text {new }}$ from about $85 \%$ to almost $91 \%$ during the Last Glacial Maximum, an increase that caused the reported $P_{\text {new }}$ growth by about 2-4 Gt $\mathrm{Cyr}^{-1}$. 'Losers' in glacial productivity were the high latitude ocean, for example, the Norwegian Sea, the circum-Antarctic ocean poleward of $50^{\circ} \mathrm{S}$ and, especially, the great subtropical gyres, which altogether make up about two-thirds of the ocean. The preglacial time slice 27-30 ky BP showed an interesting intermediate regime of the ocean, a glacial-style, rather 'polarized' Atlantic contrasting with a less polarized Holocene-style Pacific ocean.

\subsection{Variations in the Surface Water Inventory of Nutrients: The Planktonic $\delta^{13} \mathrm{C}$ Record}

Based on G. ruber which inhabits the surface mixed layer, Fig. 3 depicts over $30 \delta^{13} \mathrm{C}$ records of the nutrient content in the low and middle latitude surface ocean during the last $30 \mathrm{ky}$. Unfortunately, the low number of recent estimates does not permit systematic regional mapping to enable conclusions on the small-scale nutrient distributions in the surface water. During the last $8 \mathrm{ky}$, average $\delta^{13} \mathrm{C}$ values varied between -0.12 and +2.23 $\%$, with most of the higher estimates concentrating in the low-productivity regions such as the Sierra Leone Rise, and the lower estimates being more abundant near upwelling cells with enhanced productivity.

Figure 4 shows the planktonic $\delta^{13} \mathrm{C}$ differences between the last $8 \mathrm{ky}$ (averaged) and the LGM (17-21 ky BP). The regional variation of these difference values ranges from 
-0.3 to $+0.9 \%$ and thus largely exceeds previous, in part stacked, estimates by Broecker (1982) and Curry and Crowley (1987). We observe that negative $\delta^{13} \mathrm{C}$ differences in the surface water are well correlated with the glacial high-productivity belts. The correlation in Fig. 4 implies that the surface water of low and middle latitude glacial upwelling belts was enriched in nutrients as compared with the depleted oceanic 'deserts.' Based on measurements of Kroopnick as summarized in Broecker (1982), the maximum bandwidth in planktonic $\Delta \delta^{13} \mathrm{C}(1.2 \%)$ may reflect an additional nutrient transfer from low- to high-LGM. This transfer may provide a crucial mechanism to create the more 'polarized' paleoproductivity pattern characteristic of the LGM ocean (Fig. 2), and may, in turn, be controlled by enhanced meridional surface winds (Sarnthein et al., 1987).

$\delta^{13} \mathrm{C}$ estimates of the marked epibenthic foraminiferal species $C$. wuellerstorfi show that the $\delta^{13} \mathrm{C}$ values of the deep ocean below $2000 \mathrm{~m}$ also were subject to systematic regional changes during the LGM. On a global average they were lowered by about $0.4-0.5 \%$, and by up to $0.9 \%$ below high-productivity zones where the sea floor was frequently covered by organic fluff (Duplessy et al., 1988; Sarnthein et al., 1988). These numbers demonstrate the increased role of the glacial deep ocean as a sink for (organic

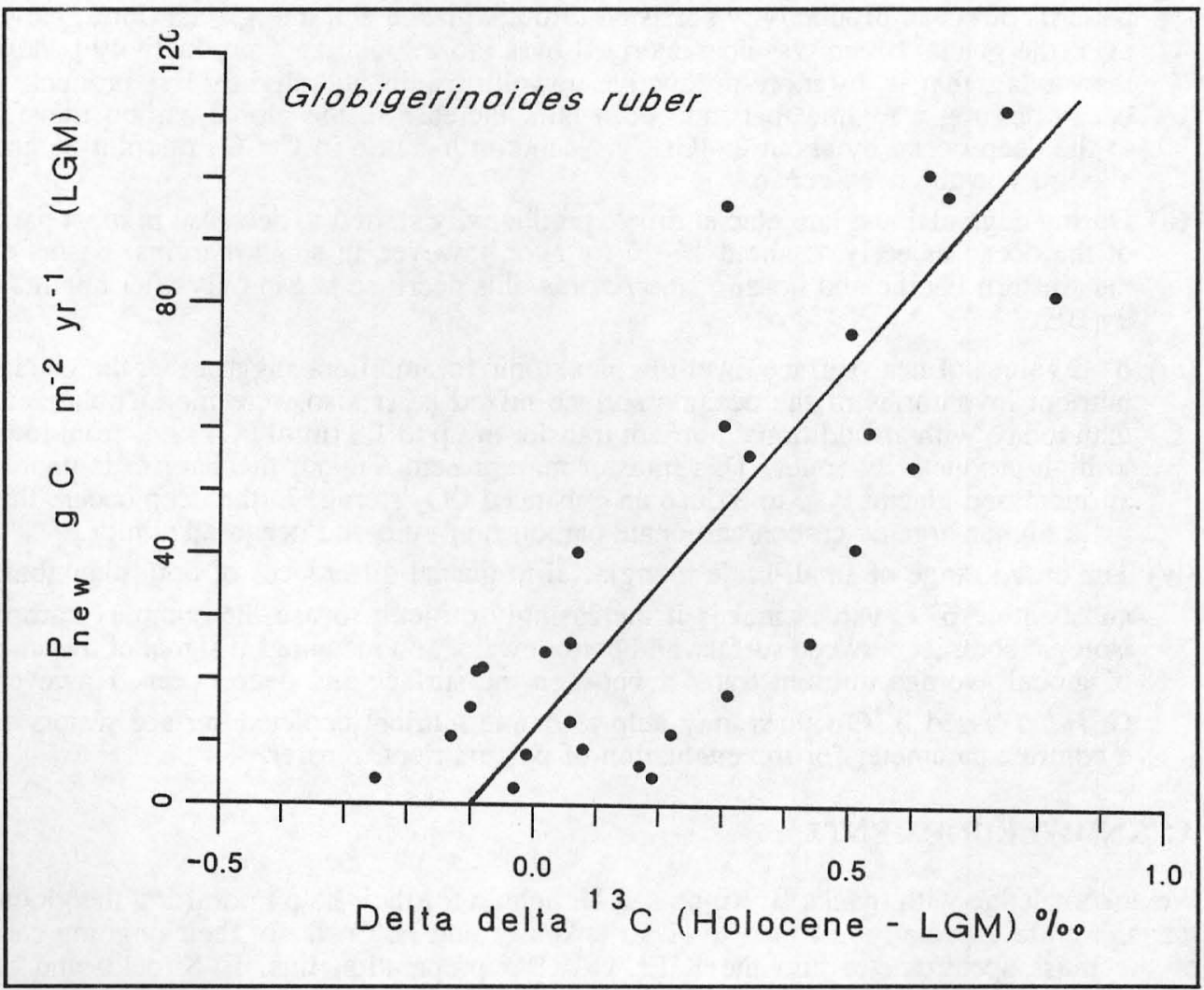

Figure 4. Holocene (last 8ky)-LGM (17-21 ky) differences of planktonic $\delta^{13} \mathrm{C}$ values versus LGM $P_{\text {new }}$ values $(G$. ruber values corrected for Glacial-Interglacial temperature anomalies based on an equation of Emrich et al. (1970) for bicarbonate-carbonate ${ }^{13} \mathrm{C}$ fractionation and CLIMAP (1981) data). The regression line shown has $r=0.81 \quad(n=28)$. 
carbon and) $\mathrm{CO}_{2}$ and nutrients, whereas the intermediate waters were $\mathrm{CO}_{2}$ depleted (Boyle, 1988; Zahn et al., 1987; Kallel et al., 1988).

The outlined broad range of interglacial-to-glacial differences of both the planktonic and benthic $\delta^{3} \mathrm{C}$ values makes it increasingly difficult to define meaningful average values of the glacial and/or interglacial carbon isotopic contrast between the surface and bottom water $\left(\Delta \delta^{13} C_{\text {Plankton-Benthos }}\right)$, and to understand the significance of these estimates at all. To a large degree they appear to be merely a result of a stochastic addition of differential, small-scale local surface and bottom water nutrient inventories rather than signals of the global nutrient transfer. (This statement does not apply to the benthic carbon isotopic contrast between Intermediate and bottom water masses sensu Boyle, 1988.) Nevertheless, our $G$. ruber results may tell which sites are representative of nutrient-depleted surface water so that one can select suitable areas for defining this contrast parameter for the evaluation of past nutrient transfers.

\section{CONCLUSIONS}

(i) Estimates of export paleoproductivity $\left(\mathrm{P}_{\text {new }}\right)$ show that the basic spatial distribution patterns of ocean productivity persisted through glacial and interglacial times. However, the glacial ocean was characterized by a more 'polarized' productivity pattern than today, that is, by more-productive upwelling cells and slightly less productive ocean deserts, a regime that induced a bulk increase in the global carbon transfer to the deep ocean by about $2-4 \mathrm{Gt} \mathrm{Cyr}^{-1}$ and an increase in $\mathrm{CaCO}_{3}$ dissolution and alkalinity in the deep ocean.

(ii) During deglacial and late glacial times, productivity started to decrease in most parts of the ocean as early as about 16-17 ky ago; however, in some marginal basins of the western Pacific and north of the Azores, this decrease began only after about 14 ky BP.

(iii) $\delta^{13} \mathrm{C}$ values of near-surface dwelling planktonic foraminifera suggest that the glacial nutrient inventories of the oceanic surface mixed layer also were more 'polarized' than today, with an additional nutrient transfer of up to $1.3 \mu \mathrm{mol} \mathrm{PO}_{4} \mathrm{~kg}^{-1}$ from lowto high-productivity zones. This transfer may present a major mechanism to enable an increased glacial $\mathrm{P}_{\text {new }}$ to induce an enhanced $\mathrm{CO}_{2}$ storage in the deep ocean, this via a higher organic carbon/carbonate carbon rain ratio and ocean alkalinity.

(iv) The broad range of small-scale interglacial-to-glacial differences of both planktonic and benthic $\delta^{13} \mathrm{C}$ values makes it increasingly difficult to use the complex carbon isotopic contrast between surface and bottom water as a meaningful signal of the state of global average nutrient transfer between the surface and deep ocean. However, $G$. ruber-based $\delta^{13} \mathrm{C}$ values may help to define nutrient-depleted surface waters as a contrast parameter for the evaluation of past nutrient transfer.

\section{ACKNOWLEDGEMENTS}

We acknowledge with thanks B. Rippe and H. Schulz for their help in drafting the global maps. We are especially indebted to $\mathrm{H}$. Erlenkeuser and $\mathrm{H}$. Cordt for their ongoing care of the mass spectrometer and the KIEL-CARBO preparation line. F. Sirocko and L. Westerhausen kindly provided unpublished data. Valuable comments by W. H. Berger and E. Boyle greatly helped to improve this paper. Financial support was provided by the National Climate Project of the German Federal Ministry of Research and Technology (BMFT), grant KF 2004/1. 


\section{REFERENCES}

Altenbach, A., and M. Sarnthein, 1989: Productivity record in benthic foraminifera. In Productivity of the Ocean: Present and Past, W. H. Berger, V. Smetacek and G. Wefer (eds.), Dahlem Konferenzen, John Wiley and Sons, Chichester, UK, pp.255269.

Barnola, J. M., D. Raynaud, Y. S. Korotkevich and C. Lorius, 1987: Vostok ice core provides 160,000-year record of atmospheric $\mathrm{CO}_{2}$. Nature, 329, 408-414.

Berger, W. H., and R. S. Keir, 1984: Glacial-Holocene changes in atmospheric $\mathrm{CO}_{2}$ and the deep-sea record. In Climate Processes and Climate Sensitivity, J. E. Hansen and T. Takahashi (eds.). Geophysical Monograph, 29, American Geophysical Union, Washington, DC, pp. 337-351.

Berger, W. H., and E. Vincent, 1986: Deep-sea carbonates: Reading the carbon-isotope signal. Geologische Rundschau, 75, 249-270.

Boyle, E. A., 1988: Vertical oceanic nutrient fractionation and glacial/interglacial $\mathrm{CO}_{2}$ cycles. Nature, 331, 55-56.

Broecker, W. S., 1982: Glacial to interglacial changes in ocean chemistry. Prog. Oceanogr., 11, 151-197.

Bruland, K. W., P. K. Bienfang, J. K. B. Bishop, G. Eglinton, V. Ittekkot, R.Lampitt, M. Sarnthein, J. Thiede, J. J. Walsh and G. Wefer, 1989: Flux to Seafloor. In Productivity of the Ocean: Present and Past, W. H. Berger, V.Smetacek and G. Wefer (eds.). Dahlem Konferenzen, John Wiley and Sons, Chichester, UK, pp.193-215.

CLIMAP, 1981: Seasonal reconstructions of the earth's surface at the last glacial maximum: By CLIMAP Project Members. In Map and Chart Series 36 (text, maps and microfiche). Geological Society of America, Denver, CO.

Curry, W. B., R. C. Thunell and S. Honjo, 1983: Seasonal changes in the isotopic composition of planktonic foraminifera collected in Panama Basin sediment traps. Earth Planet. Sci. Lett., 64, 33-43.

Curry, W. B., and G. P. Lohmann, 1985: Carbon deposition rates and deep water residence time in the equatorial Atlantic Ocean throughout the last 160,000 years. In The Carbon Cycle and Atmospheric $\mathrm{CO}_{2}$, Natural Variations-Archean to Present, E. T. Sundquist and W. S. Broecker (eds.). Geophysical Monograph, 32, American Geophysical Union, Washington, DC, pp. 285-301.

Curry, W. B., and T. J. Crowley, 1987: $\delta^{13} \mathrm{C}$ in equatorial Atlantic surface waters: Implications for Ice Age $\mathrm{pCO}_{2}$ levels. Paleoceanography, 2, 489-518.

Deuser, W. G., and E. H. Ross, 1980: Seasonal change in the flux of organic carbon to the deep Sargasso Sea. Nature, 283, 364-365.

Deuser, W. G., E. H. Ross, C. Hemleben and M. Spindler, 1981: Seasonal changes in species composition, numbers, mass, size and isotopic composition of planktonic foraminifera settling in the deep Sargasso Sea. Palaeogeogr., Palaeoclimatol., Palaeocol., 33, 103-127.

Duplessy, J.-C., J. Moyes and C. Pujol, 1980: Deep water formation in the North Atlantic Ocean during the last Ice Age. Nature, 286, 479-482.

Duplessy, J.-C., 1981: North Atlantic deep water circulation during the last climatic cycle. Bull. d'Institute Geol. du Bassin d'Aquitaine, Bordeaux, 31, 379-391.

Duplessy, J.-C., N. J. Shackleton, R. K. Matthews, W. Prell, W. F. Ruddiman, M.Caralp and C. H. Hendy, 1984: $\delta^{13} \mathrm{C}$ record of benthic foraminifera in the last Interglacial Ocean: Implications for the carbon cycle and the global deep water circulation. Quat. Res., 21, 225-243. 
Duplessy, J.-C., N. J. Shackleton, R. G. Fairbanks, L. D. Labeyrie, D. Oppo, and N.Kallel, 1988: Deep water source variations during the last climatic cycle and their impact on the global deep-water circulation. Paleoceanography, 3, 343-360.

Emerson, S., K. Fischer, C. Reimers and D. Heggie, 1985: Organic carbon dynamics and preservation in deep-sea sediments. Deep-Sea Res., 32, 1-21.

Emrich, K., D. H. Ehhalt and J. C. Vogel, 1970: Carbon isotope fractionation during the precipitation of calcium carbonate. Earth Planet. Sci. Lett., 8, 363-371.

Eppley, R., and B. J. Peterson, 1979: Particulate organic matter flux of planktonic new production in the deep ocean. Nature, 282, 677-680.

Fairbanks, R. G., M. Sverdlove, R. Free, P. H. Wiebe and A. W. H. Be, 1982: Vertical distribution and isotopic fractionation of living planktonic foraminifera from the Panama Basin. Nature, 298, 841-844.

Fontugne, M. R., and J.-C. Duplessy, 1981: Organic carbon isotopic fractionation by marine plankton in the temperature range -1 to $31^{\circ} \mathrm{C}$. Oceanol. Acta, 4, 85-90.

Fontugne, M. R., and J.-C. Duplessy, 1986: Variations in the monsoon regime during the upper Quaternary: Evidence from carbon isotopic record of organic matter in North Indian Ocean sediment cores. Palaeogeogr., Palaeoclimatol., Palaeocol., 56, 69-88.

Ganssen, G., 1983: Dokumentation von küstennahem Auftrieb anhand stabiler Isotopen in rezenten Foraminiferen vor Nordwest-Afrika. "Meteor" Forschungsergebnisse, C 37, 1-46.

Hansen, J. E., A. Lacis, D. Rind, G. Russell, P. Stone, R. Ruedy and J. Lerner, 1984: Climate sensitivity: analysis of feedback mechanisms. In Climate Processes and Climate Sensitivity, J. E. Hansen and T. Takahashi (eds.). Geophysical Monograph, 29, American Geophysical Union, Washington, DC, pp. 337-351.

Hemleben, C., M. Spindler and O. R. Anderson, 1989: Modern planktonic foraminifera. Springer, NY, $363 \mathrm{pp}$.

Ittekkot, V., 1988: Global trends in the nature of organic matter in river suspensions. Nature, 332, 436-438.

Jansen, E., and H. Erlenkeuser, 1984: Ocean circulation in the Norwegian Sea during the Last Deglaciation: Isotopic Evidence. Palaeogeogr., Palaeoclimatol., Palaeocol., 49, 189-206.

Jansen, J. H. F., T. C. E. van Weering, R. Gides and J. van Iperan, 1984: Middle and Late Quaternary oceanography and climatology of the Zaire-Congo fan and the adjacent eastern Angola Basin. Neth. J. Sea Res., 17 (2-4), 201-249.

Kallel, N., L. D. Labeyrie, A. Juillet-Leclerc and J.-C. Duplessy, 1988: A deep hydrological front between intermediate and deep-water masses in the glacial Indian Ocean. Nature, 333, 651-655.

Kassens, H., and M. Sarnthein, 1989: A link between paleoceanography, early diagenetic cementation, and shear strength maxima in late Quaternary deep-sea sediments? Paleoceanography 4, 253-269.

Koblentz-Mishke, O. J., V. V. Volkowinsky and J. G. Kabanova, 1970: Plankton primary production of the World Ocean. In Scientific Exploration of the South Pacific, W. S. Wooster (ed.), National Academy of Science, Washington, DC, pp. 183-193.

Kroopnick, P., 1971: Oxygen and carbon in the oceans and atmosphere: Stable isotopes as tracers for consumption, production and circulation models. Ph.D. Thesis, University of California, San Diego, $230 \mathrm{pp}$.

Lochte, K., and C. M. Turley, 1988: Bacteria and cyanobacteria associated with phytodetritus in the deep sea. Nature, 333, 67-69.

Lutze, G. F., and H. Thiel, 1987: Cibicidoides wuellerstorfi and Planulina ariminensis, elevated epibenthic foraminifera. Berichte Sonderforschungsbereich 313, Universität Kiel, 6, 17-30. 
Lutze, G. F., and H. Thiel, 1989: Epibenthic foraminifera from elevated microhabitats: Cibicidoides wuellerstorfi and Planulina ariminensis. J. Foram. Res., 19, 153-158.

Lyle, M., D. W. Murray, B. P. Finney, J. Dymond, J. M. Robbins and K. Brooksforce, 1988: The record of late Pleistocene biogenic sedimentation in the eastern tropical Pacific Ocean. Paleoceanography, 3, 39-59.

Mitchell, J. F. B., 1988: Local effects of greenhouse gases. Nature, 332, 399-400.

Mix, A. C., 1989: Influence of productivity variations on long-term atmospheric $\mathrm{CO}_{2}$. Nature, 337, 541-544.

Morris, R. J., M. J. McCartney and P. P. E. Weaver, 1984: Sapropelic deposits in a sediment core from the Guinea Basin, South Atlantic. Nature, 309, 611-614.

Müller, P. J., and A. Mangini, 1980: Organic carbon decomposition rates in sediments of the Pacific manganese nodule belt dated by $230 \mathrm{Th}$ and $231 \mathrm{~Pa}$. Earth Planet. Sci. Lett., 51, 94-114.

Müller, P. J., and E. Suess, 1979: Productivity, sedimentation rate, and sedimentary organic matter in the oceans-I. Organic carbon preservation. Deep-Sea Res., 26, 1347-1362.

Pedersen, T. F., M. Pickering, J. S. Vogelsang, J. N. Southon and D. E. Nelson, 1988: The response of benthic foraminifera to productivity cycles in the eastern equatorial Pacific: Faunal and geochemical constraints on glacial bottom water bottom oxygen levels. Paleoceanography, 3, 157-168.

Pflaumann, U., 1989: Temperaturreaktionen des nordöquatorialen Atlantiks auf globale Klima-Anfachung während der letzten 750.000 Jahre. Paläoklimaforschung Akad. Wiss. Lit. Mainz (in press).

Prell, W. L., and W. B. Curry, 1980: Faunal and isotopic indices of monsoonal upwelling: Western Arabian Sea. Oceanol. Acta, 4, 91-98.

Sarnthein, M., H. Erlenkeuser, R. v. Grafenstein and C. Schroeder, 1984: Stable isotope stratigraphy for the last 750,000 years: "Meteor" core 13519 from the eastern equatorial Atlantic. "Meteor" Forschungsergebnisse, C 38, 9-24.

Sarnthein, M., K. Winn and R. Zahn, 1987: Paleoproductivity of oceanic upwelling and the effect on atmospheric $\mathrm{CO}_{2}$ and climatic change during deglaciation times. In Abrupt Climatic Change, W.H. Berger and L.D. Labeyrie (eds.). Reidel, Dordrecht, pp.311-337.

Sarnthein, M., K. Winn, J.-C. Duplessy and M. Fontugne, 1988: Global carbon variations of surface ocean productivity in low and mid latitudes: Influence on $\mathrm{CO}_{2}$ reservoirs of the deep ocean and atmosphere during the last 21,000 years. Paleoceanography, 3, 361-399.

Shackleton, N. J., 1977: Carbon-13 in Uvigerina: Tropical rainforest history and the equatorial Pacific carbonate dissolution cycles. In The Fate of Fossil Fuel in the Oceans, N. R. Andersen and A. Malahoff (eds.). Plenum Press, NY, pp. 401-427.

Shackleton, N. J., M. A. Hall, J. Line and C. Shuxi, 1983: Carbon isotope data in core V19-30 confirm reduced carbon dioxide concentration in the ice age atmosphere. Nature, 306, 319-322.

Sirocko, F., 1989: Zur Akkumulation von Staubsedimenten im nördlichen Indischen Ozean: Anzeiger der Klimageschichte Arabiens und Indiens, Berichte-Reports Geol. Paläont. Inst. Univ. Kiel, 27, 114 pp.

Stevenson, F. J., and C. N. Cheng, 1972: Organic geochemistry of Argentine Basin sediments: Carbon-nitrogen relationships and Quaternary correlations. Geochemica et Cosmochemica Acta, 36, 653-671.

Suess, E., 1980: Particulate organic carbon flux in the ocean's relation to surface productivity and oxygen utilization. Nature, 288, 260-263. 
Sundquist, E. T., and W. S. Broecker, 1985: The carbon cycle and atmospheric $\mathrm{CO}_{2}$, natural variations Archean to present. Geophysical Monograph, 32, American Geophysical Union, Washington, DC, 627 pp.

Woodruff, F., and S. M. Savin, 1985: $\delta^{13} \mathrm{C}$ values of Miocene Pacific benthic foraminifera: Correlations with sea level and biological productivity. Geology, 13, 119-122.

Zahn, R., 1982: Zur jungquartären Entwicklung vom Klima und Ozeanographie am NWAustralischen Kontinentalrand $\left(17^{\circ} \mathrm{S}\right)$. M.Sc. Thesis, Universität Kiel, 40 pp.

Zahn-Knoll, R., 1986: Spätquartäre Entwicklung von Küstenauftrieb und Tiefenwasserzirkulation im Nordost-Atlantik. Rekonstruktion anhand stabiler Isotope kalkschaliger Foraminiferen. Doc. Dissertation Math. Naturw. Fakultät, ChristianAlbrechts-Universität Kiel, 112 pp.

Zahn, R., K. Winn, and M. Sarnthein, 1986: Benthic foraminiferal $\delta^{13} \mathrm{C}$ and accumulation rates of organic carbon: Uvigerina peregrina group and Cibicidoides wuellerstorfi. Paleoceanography, 1, 27-42.

Zahn, R., M. Sarnthein, and H. Erlenkeuser, 1987: Benthos isotopic evidence for changes of the Mediterranean outflow during the Late Quaternary. Paleoceanography, 2, 543-559. 